\section{References}

1 Tobian L Jr, Binion JT. Tissue cations and water in arterial hypertension. Circulation 1952;5:754-8.

${ }^{2}$ Losse $\mathrm{H}$, Wehmeyer $\mathrm{H}$, Wessels $\mathrm{F}$. The water and electrolyte content of erythrocytes in arterial hypertension. Klin Wochenschr 1960;38:393-5.

${ }^{3}$ Gessler Von U. Intra-und extrazelluläre elektrolytveränderungen bei essentieller hypertonie bor und nach behandlung. $Z$ Kreislaufforsch $1962 ; 51: 177-83$

${ }^{4}$ Wessels VF, Junoe-Hüsling G, Losse $H$. Unter suchungen zur natriumpermeabilität der erythrozyten bei hypertonikern und normotonikern mit familiärer hochdruckbelastung. $Z$ Kreislaufforsch 1967;56:374-80.

${ }^{5}$ Postnov YV, Orlov SN, Shevchenko A. Adler AM. Altered sodium permeability, calcium binding and Na-K-ATPase activity in the red blood cell membrane in essential hypertension. Pfluegers Arch 1977;371 : 263-9.

${ }^{6}$ Garay RP, Meyer P. A new test showing abnormal net $\mathrm{Na}^{+}$and $\mathrm{K}^{+}$fluxes in erythrocytes of essential hypertensive patients. Lancet 1979;i:349-53.

${ }^{7}$ Henningsen NC, Mattsson S, Nosslin B, Nelson D, Ohlsson O. Abnormal whole-body and cellular (erythrocytes) turnover of ${ }^{22} \mathrm{Na}^{+}$in normotensive relatives of probands with established essential hypertension. Clinical Science 1979;57:321-4s.

${ }^{8}$ Edmondson RPS, Thomas RD, Hilton PJ, Patrick J, Jones NF. Abnormal leucocyte composition and sodium transport in essential hypertension. Lancet 1975 ; : $1003-5$.

9 Thomas RD, Edmondson RPS, Hilton PJ, Jones NF. Abnormal sodium transport in leucocytes from patients with essential hypertension and the effect of treatment. Clinical Science and Molecular Medicine 1975; 48:169-70s.

10 Ambrosioni E, Tartagni F, Montebugnoli L, Magnani B. Intralymphocytic sodium in hypertensive patients: a significant correlation. Clinical Science 1979;57:325-7s.

11 Garay RP, De Mendonca M, Elghozi JL, et al. Clinical and pathological relevance of erythrocyte cation fluxes measurement in hypertension. Clinical Science 1979;57:329-31s.

12 Araoye MA, Khatri IM, Yao LLY, Freis ED. Intracellular sodium in hypertensive patients. Clinical Research 1978;26:53.

13 Aderounmu AF, Salako LA. Abnormal cation composition and transport in erythrocytes from hypertensive patients. Eur $\mathcal{F}$ Clin Invest 1979;9: 369-75.
14 de Wardener HE, MacGregor GA. Hypothesis: further observations on Dahl's hypothesis that a saluretic substance may be responsible for a sustained rise in arterial pressure. Its possible role in essential hypertension. Kidney Int 1980;18:1-9.

15 Jones R, Poston L, Hinestrosa H, Parsons V, Williams R. Weight gain between dialyses in diabetics: possible significance of raised intracellular sodium content. Br Med f 1980;280:153.

${ }^{16}$ Hilton PJ, Patrick J. Sodium and potassium flux rates in normal leucocytes in an artificial extracellular fluid. Clinical Science $1973 ; 44: 439-45$.

17 Alam AN, Poston L, Wilkinson SP, Golindano CG, Williams R. A study in vitro of the sodium pump in fulminant hepatic failure. Clinical Science and Molecular Medicine 1978;55:255-63.

${ }^{18}$ Glynn M. Sodium and potassium measurements in human red cells. $\mathcal{F}$ Physiol (Lond) 1956;134:278-310.

19 DahI LK, Knudsen KD, Iwai J. Humoral transmission of hypertension: evidence from parabiosis. Circ Res 1969;24.25, suppl 1:21-33.

20 Tobian L, Coffee K, McCrea P, Dahl LK. A comparison of the antihypertensive potency of kidneys from one strain of rats susceptible to salt hypertension and kidneys from another strain resistant to it. $\mathcal{F ~ C l i n}$ Invest $1966 ; 45: 1080$.

${ }^{21}$ Dahl LK, Heine M. Primary role of renal homografts in setting chronic blood pressure levels in rats. Circ Res 1975;36:692-6.

${ }^{22}$ Dahl LK, Heine M, Thompson K. Genetic influence of the kidneys on blood pressure. Evidence from chronic renal homografts in rats with opposite predispositions to hypertension. Circ Res 1974;34:94-101.

${ }^{23}$ Bianchi G, Fox U, Di Francesco GF, Giovanetti AM, Pagetti D. Blood pressure changes produced by kidney cross-transplantation between spontaneously hypertensive rats and normotensive rats. Clinical Science and Molecular Medicine 1974;47:435-48.

${ }^{24}$ Fox U, Bianchi G. The primary role of the kidney in causing the blood pressure difference between the Milan hypertensive strain (MHS) and normotensive rats. Clin Exp Pharmacol Physiol 1976;3, suppl:71-4.

${ }^{25}$ Birkenhager WH. Body-fluid volume in low-renin hypertension. Lancet $1974 ;$ ii:310-1.

26 Blaustein MP. Sodium ions, calcium ions, blood pressure regulation, and hypertension: a reassessment and a hypothesis. Am $\mathcal{F}$ Physiol 1977;232 (3):C165-73.

(Accepted 5 fanuary 1981)

\title{
Glucose turnover and metabolic and hormonal changes in ethanol-induced hypoglycaemia
}

\author{
N M WILSON, P M BROWN, S M JUUL, S A PRESTWICH， P H SÖNKSEN
}

\begin{abstract}
Infusion of $67 \mathrm{~g}$ ethanol over four hours in fasted, nonobese normal men (a) induced hypoglycaemia by inhibiting gluconeogenesis; (b) produced noticeable increases in blood lactate, 3-hydroxybutyrate, and free fatty acid concentrations; (c) depressed plasma growth hormone concentrations, despite hypoglycaemia; and (d) raised plasma cortisol concentrations before significant hypoglycaemia occurred. These metabolic changes were explained by the reduction of redox state which accompanies ethanol oxidation.

The pronounced changes in metabolic values recorded during this study suggested that the use of parenteral feeding regimens including ethanol needs to be reconsidered.
\end{abstract}

Department of Medicine, St Thomas's Hospital Medical School, London SE1 7EH

N M WILSON, BSC, medical student

$P$ M BROWN, $M B$, BS, lecturer in medicine

$S$ M JUUL, MSC, research fellow

S A PRESTWICH, HNC, medical laboratory scientific officer

P H SÖNKSEN, MD, FRCP, professor of endocrinology

\section{Introduction}

Ethanol-induced hypoglycaemia was first described by Brown and Harvey in 1941. ${ }^{1}$ The belief that chronic alcoholism was a prerequisite for the condition was refuted by several reports of its occurrence in children. Initially the hypoglycaemia was attributed to the hepatotoxicity of denatured alcohol solvents, and it was not until 1963 that ethanol alone was shown to be responsible." The pathophysiology of the condition is still not clear. The in-vitro studies of Freinkel $e t a l^{3}$ indicated that inhibition of glucose production was responsible, while Searle et $a l,{ }^{4}$ using metabolic tracer studies in vivo, implicated an increase in glucose utilisation.

In addition to its effect on glucose homoeostasis, ethanol metabolism reduces the cytosolic and mitochondrial redox states, $^{5}$ thus causing many changes in intermediary carbohydrate and fat metabolism. The effect of ethanol on the plasma free fatty acid concentration, however, is controversial: Freinkel et $a l^{2}$ reported a net rise, while Abramson and Arky ${ }^{6}$ observed a net fall. The response of ketone bodies is also not clear. Arky and Freinkel ${ }^{7}$ found a decline in blood acetoacetate concentration in response to ethanol oxidation, while Bagdade et $^{a^{8}}$ observed a rise. That insulin-induced hypoglycaemia leads to raised plasma growth hormone and cortisol concentrations is well known, but the hormonal response to acute alcohol ingestion is 
Blood ethanol, metabolite, and plasma potassium concentrations before and during ethanol infusion. Values are means i SEM; results shown at various times from start of experiment

\begin{tabular}{|c|c|c|c|c|c|c|c|}
\hline & \multicolumn{3}{|c|}{ Equilibration } & \multicolumn{4}{|c|}{ Ethanol infusion } \\
\hline & $90 \mathrm{~min}$ & $150 \mathrm{~min}$ & $210 \mathrm{~min}$ & $270 \mathrm{~min}$ & $330 \mathrm{~min}$ & $390 \mathrm{~min}$ & $450 \mathrm{~min}$ \\
\hline Ethanol (mmol/1) & & & & $\begin{array}{c}4.57+0.16 \\
\text { NS }\end{array}$ & $\begin{array}{c:c}8.78 & 0.43 \\
\text { NS }\end{array}$ & $\begin{array}{r}11 \cdot 36: 0.61 \\
\text { NS }\end{array}$ & $15 \cdot 10+0 \cdot 70$ \\
\hline Pyruvate $(\mu \mathrm{mol} / \mathrm{l})$ & $26 \cdot 0 \pm 3 \cdot 0$ & $32 \cdot 0+8 \cdot 0$ & $24 \cdot 0+3 \cdot 0$ & $25 \cdot 0+5 \cdot 0$ & $25.0+6.0$ & $36 \cdot 0: 10 \cdot 0$ & $56.0+17.0$ \\
\hline Acctoacetate ( $\mathrm{mmol} / \mathrm{l})$ & $0.29 \pm 0.005$ & $0.31+0.04$ & $0.26: 0.05$ & $0 \cdot 17: 0.05$ & $0 \cdot 14: 0 \cdot 04$ & $0 \cdot 16+\underset{t}{0.02}$ & $0.18+0.02$ \\
\hline Glycerol (mmol/1) & $0 \cdot 10 \pm 0 \cdot 01$ & $0.10 \doteq 0.01$ & $0.11+0.01$ & $0 \cdot 17+0.04$ & $0.24: 0.03$ & $0 \cdot 29 \pm 0 \cdot 16$ & $0.30 \div 0.05$ \\
\hline Potassium (mmol/l) & $3.75 \pm 0.05$ & $3.82+0.07$ & $3.87 \div 0.04$ & $3.68 \div 0.09$ & $3.52: 0 \cdot 10$ & $3.38: 0.05$ & $3.40: 0.09$ \\
\hline
\end{tabular}

Compared with values at 210 minutes: NS $=$ not significant; $* p<0.05 ; \dagger p<0.01$

Conversion: SI to traditional units-Ethanol: $1 \mathrm{mmol} / 1 \approx 4.6 \mathrm{mg} / 100 \mathrm{ml}$. Pyruvate: $1 \mu \mathrm{mol} / 1 \approx 0.009 \mathrm{mg} / 100 \mathrm{ml}$. Acetoacetate: $1 \mathrm{mmol} / \mathrm{l} \approx 10 \cdot 2 \mathrm{mg} / 100 \mathrm{ml}$. Glycerol: 1 $\mathrm{mmol} / 19 \cdot 2 \mathrm{mg} / 100 \mathrm{ml}$. Potassium: $1 \mathrm{mmol} / 1=1 \mathrm{mEq} / 1$.

unresolved. We therefore investigated the effects of ethanol infusion on glucose turnover, intermediary carbohydrate and fat metabolite concentrations, and insulin, growth hormone, and cortisol concentrations in normal subjects.

\section{Subjects and methods}

Experiments were performed on six normal, non-obese male medical students. Written, informed consent was obtained from all subjects, ethical approval of the project having been granted by the hospital's ethical committee.

Studies were performed in the morning after a 36-hour fast, during which only clear fluids were taken. Three cannulae were inserted into antecubital veins, one being used for blood sampling and the other two for infusions. At the beginning of the study (time 0 ) a priming dose of 3-tritiated glucose (Radiochemical Centre, Amersham) was given followed by a constant infusion of the labelled glucose for the duration of the study. After an equilibration period of three and a half hours a $15 \%$ solution of ethanol in isotonic saline was infused through a separate cannula at $120 \mathrm{ml} / \mathrm{h}(16.8 \mathrm{~g}$ ethanol/h) for four hours. After three hours of ethanol infusion a $1 \mathrm{mg}$ bolus of glucagon was injected intravenously over one minute.

Blood samples were taken from the other arm at one and a half hours and at 10-minute intervals thereafter for measurement of plasma glucose, glucose-specific activity, blood lactate, pyruvate, 3-hydroxybutyrate, acetoacetate, glycerol and plasma free fatty acids, growth hormone, cortisol, insulin, and potassium. Blood alcohol was assayed enzymatically. Plasma glucose was measured by a glucose oxidase method after deproteinisation and lyophilisation by liquid scintillation counting, and the rates of appearance $(\mathbf{R a})$ and disappearance $(\mathrm{Rd})$ of glucose were calculated by the method of Steele $e t$ al. ${ }^{9}$ Lactate and pyruvate, 3-hydroxybutyrate, and acetoacetate were assayed in deproteinised blood by enzymatic spectrophotometry. Plasma free fatty acids were measured by fluorometry after Dole extraction. Plasma growth hormone, cortisol, and insulin were measured by radioimmunoassay using specific antisera, and plasma potassium by flame photometry.

Standard statistical analyses were by paired and unpaired $t$ tests, Bessel's correction of variance for standard errors of the mean (SEM) being employed.

\section{Results}

\section{BLOOD ETHANOL}

Blood ethanol concentrations (table) increased steadily during infusion, reaching a peak $15.1 \pm 0.7 \mathrm{mmol} / 1(69.6 \pm 3.2 \mathrm{mg} / 100 \mathrm{ml}$; mean \pm SEM) at 450 minutes, the end of the experiment. All subjects felt deeply intoxicated despite these relatively low blood ethanol concentrations.

\section{PLASMA GLUCOSE, GLUCOSE TURNOVER, AND INSULIN}

Plasma glucose concentrations (fig 1 ) were fairly constant at 3.7 $\mathrm{mmol} / 1(66.7 \mathrm{mg} / 100 \mathrm{ml})$ during the equilibration period. These fell significantly $(\mathrm{p}<0.01)$ during ethanol infusion, reaching a nadir of $2.2 \pm 0.22 \mathrm{mmol} / 1(39.6 \pm 4.0 \mathrm{mg} / 100 \mathrm{ml}) 230$ minutes after the start of the infusion. Injection of glucagon at 390 minutes caused no significant change in plasma glucose concentration.

The mean preinfusion values of $\mathrm{Ra}$ and $\mathrm{Rd}$ (fig 1 ) were $8.72 \pm 0.45$ $\mu \mathrm{mol} / \mathrm{min} / \mathrm{kg}$ and $8.88 \pm 0.26 \mu \mathrm{mol} / \mathrm{min} / \mathrm{kg}(1.57$. $0.08 \mathrm{mg}$ and $1.60 \pm 0.05 \mathrm{mg} / \mathrm{min} / \mathrm{kg}$ ) respectively and were not significantly different. Ethanol infusion was accompanied by a significant $(p<0.05)$ reduction in $\mathrm{Ra}$, which reached a nadir of $5.61+0.60 \mu \mathrm{mol} / \mathrm{min} / \mathrm{kg}$ $(1.01 \pm 0.11 \mathrm{mg} / \mathrm{min} / \mathrm{kg}) 180$ minutes after the infusion was started.
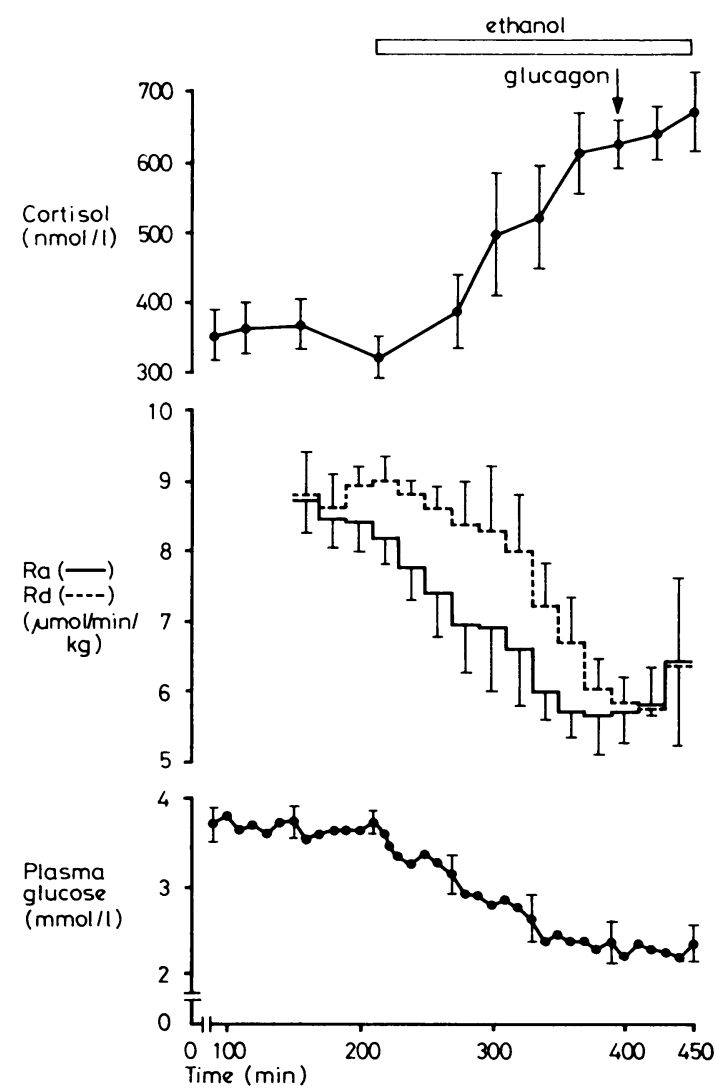

FIG 1-Mean plasma cortisol concentration, rates of appearance $(\mathrm{Ra})$ and disappearance $(\mathrm{Rd})$ of glucose, and plasma glucose concentration ( $t$ SEM) before and Juring ethanol infusion.

Conversion: SI to traditional units-Cortisol: $1 \mathrm{nmol} / \mathrm{l} \approx$ $0.04 \mu \mathrm{g} / 100 \mathrm{ml}$. Ra, Rd glucose: $1 \mu \mathrm{mol} \approx 0.18 \mathrm{mg}$. Glucose : $1 \mathrm{mmol} / 1 \approx 18 \mathrm{mg} / 100 \mathrm{ml}$.

Rd also fell during ethanol infusion, but the fall began later than that of $\mathrm{Ra}$ and its magnitude was less (nadir $5.72 \pm 0.62 \mu \mathrm{mol} / \mathrm{min} / \mathrm{kg}$ $(1.03 \pm 0.11 \mathrm{mg} / \mathrm{min} / \mathrm{kg}) 200$ minutes after start of infusion). Ra was significantly lower than $\mathrm{Rd}(\mathrm{p}<0.05)$ during the period 230 350 minutes. Glucagon caused no significant change in Ra or Rd.

Plasma insulin concentration remained at or below $1 \mathrm{mU} / \mathrm{l}$ (the lower limit of the insulin radioimmunoassay) throughout the experiment, and there was no response to the glucagon injection. 


\section{INTERMEDIATE METABOLITES AND FREE FATTY ACIDS}

Mean blood lactate concentration (fig 2) during equilibrium was steady at $0.64 \mathrm{mmol} / 1(5.77 \mathrm{mg} / 100 \mathrm{ml})$. A significant rise $(\mathrm{p}<0.001)$ occurred during ethanol infusion, the peak value of $3.25: 0.51$ $\mathrm{mmol} / 1(29.28 \div 4.59 \mathrm{mg} / 100 \mathrm{ml})$ being reached at the end of the experiment. Blood pyruvate concentration (table) remained steady during the equilibration period at $28.0 \mu \mathrm{mol} / 1(0.25 \mathrm{mg} / 100 \mathrm{ml})$ and rose slightly during ethanol infusion, the peak value of 56.0 . $17.0: 2 \mathrm{~mol} / \mathrm{l}(0.49: 0.15 \mathrm{mg} / 100 \mathrm{ml})$ at 450 minutes being significantly different $(\mathrm{p}<0.05)$ from the preinfusion value. The lactate to pyruvate ratio (fig 2 ) increased $(p<0.05)$ from a preinfusion value of about 25 to a peak of $77 \cdot 3+19.5180$ minutes after the start of ethanol infusion. The highest individual value was $159 \cdot 3$.

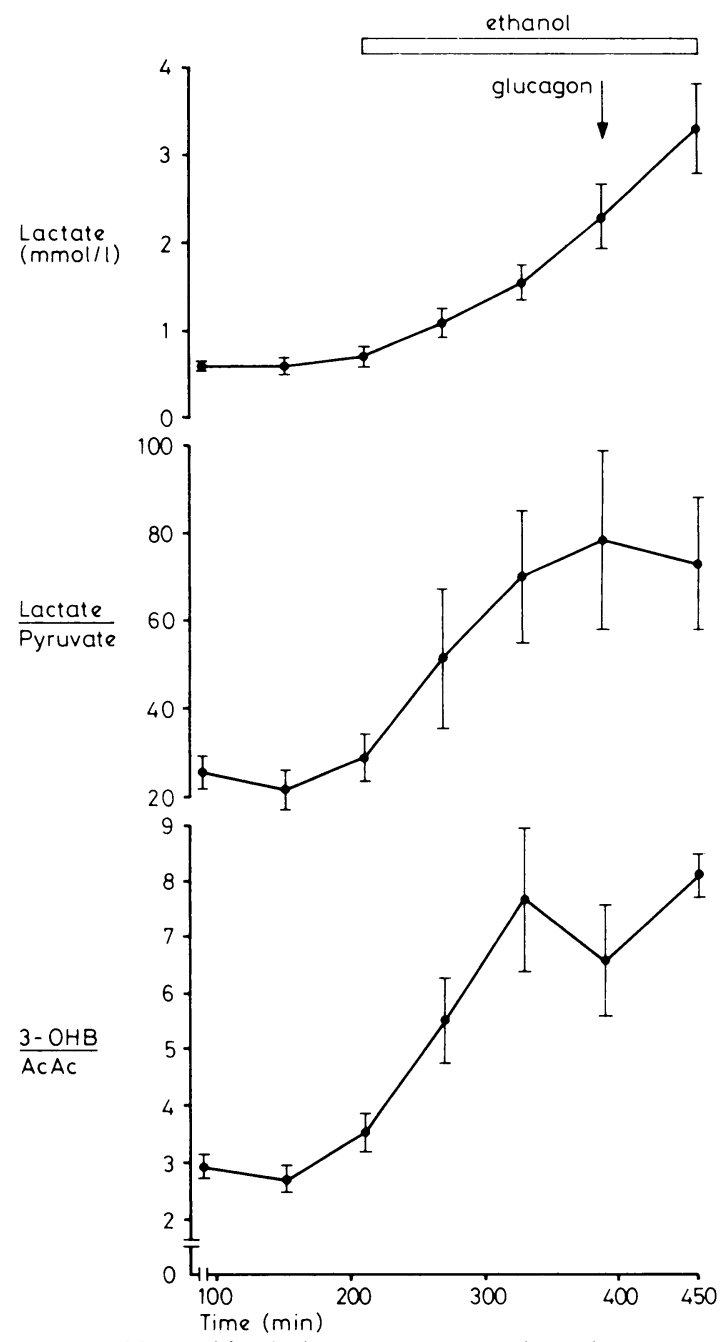

FIG 2-Mean blood lactate concentration, lactate to pyruvate ratio, and 3-hydroxybutyrate to acetoacetate (3-OHB AcAc) ratio (: SEM) before and during ethanol infusion.

Conversion: SI to traditional units-Lactate: $1 \mathrm{mmol} / 1$ $\approx 9 \mathrm{mg} / 100 \mathrm{ml}$.

Following steady equilibration values of $0.88 \mathrm{mmol} / 1(9 \cdot 16 \mathrm{mg}$ $100 \mathrm{ml})$, blood 3-hydroxybutyrate concentrations rose to a peak of $1.46 \therefore 0.70 \mathrm{mmol} / \mathrm{i}(15.20+7.29 \mathrm{mg} / 100 \mathrm{ml})$ at the end of the experiment $(p<0.001)$. During ethanol infusion blood acetoacetate concentrations (table) fell from the 210 -minute preinfusion value of $0 \cdot 26$ $0.05 \mathrm{mmol} / 1(2.65: 0.51 \mathrm{mg} / 100 \mathrm{ml})$ to $0.14 \div 0.04 \mathrm{mmol} / 1(1.40$ $0.38 \mathrm{mg} / 100 \mathrm{ml})$ at 300 minutes $(\mathrm{p}<0.05)$. The 3-hydroxybutyrate to acetoacetate ratio (fig 2 ) varied little during the equilibration period, averaging 3 . Ethanol infusion produced a rise in the ratio, which reached $8.12 \div 0.44$ at the end of the experiment $(p<0.001)$.

Blood glycerol concentration (table) remained steady at $0 \cdot 10$ $\mathrm{mmol} / \mathrm{l}(0.92 \mathrm{mg} / 100 \mathrm{ml})$ during equilibration, and rose during ethanol infusion to a peak of $0.30 \ldots 0.05 \mathrm{mmol} / 1(2.76 \pm 0.46 \mathrm{mg} / 100$ $\mathrm{ml})$ at the end of the experiment $(\mathrm{p}<0 \cdot 01)$. Free fatty acid concentration (fig 3) also showed little variation during equilibration, being approximately $1.1 \mathrm{mmol} / 1(28.2 \mathrm{mg} / 100 \mathrm{ml})$. The initial fall in free fatty acid concentrations after the start of the ethanol infusion was followed by a significant rise to a plateau of $2.49 \pm 0.2 \mathrm{mmol} / 1(63.7 \pm$ $5.1 \mathrm{mg} / 100 \mathrm{ml})(\mathrm{p}<0.001)$, which was maintained from 390 minutes to the end of the experiment.

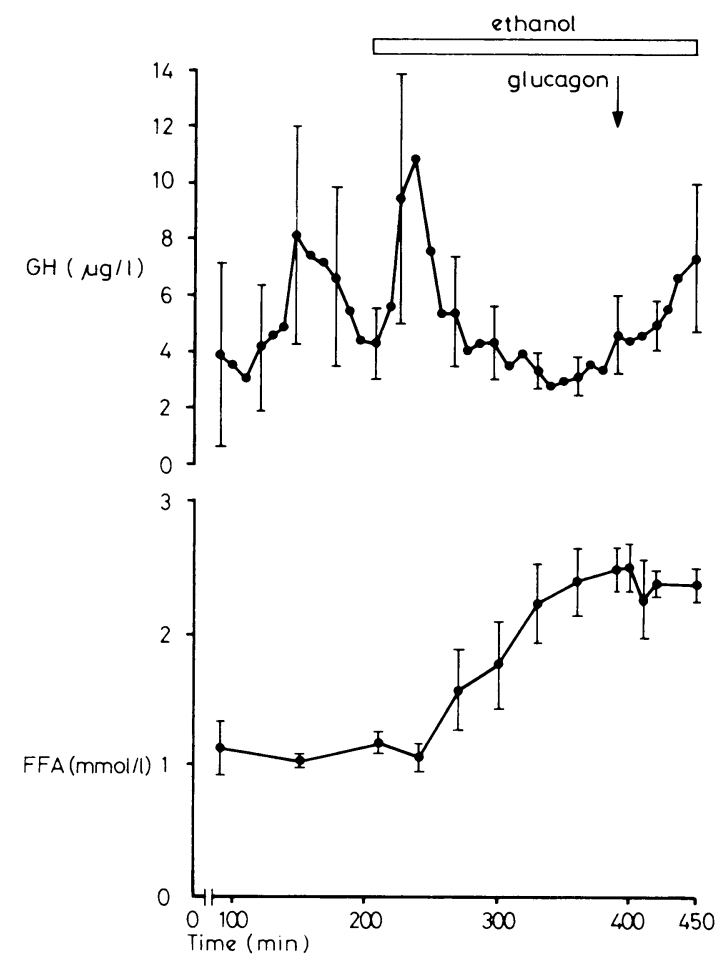

FIG 3-Mean plasma growth hormone $(\mathrm{GH})$ and free fatty acid (FFA) concentrations ( $\$$ SEM) before and during ethanol infusion.

Conversion: SI to traditional units-FFA: $1 \mathrm{mmol} / \mathrm{l}$ $\approx 25.6 \mathrm{mg} / 100 \mathrm{ml}$

\section{GROWTH HORMONE AND CORTISOL}

Characteristic fluctuations in plasma growth hormone concentration (fig 3) were evident during the equilibration period. These were less apparent during ethanol infusion, and concentrations fell significantly to $2.70 \pm 0.52 \mu \mathrm{g} / \mathrm{l}$ at 340 minutes $(\mathrm{p}<0.05)$. The later rise was not significant.

Plasma cortisol concentration (fig 1) was steady at $340 \mathrm{nmol} / 1$ $(12 \mu \mathrm{g} / 100 \mathrm{ml})$ during equilibration and rose to a peak of $654 \pm 50$ $\mathrm{nmol} / \mathrm{l}(24 \pm 1.8 \mu \mathrm{g} / 100 \mathrm{ml})$ at the end of the experiment $(\mathrm{p}<0.01)$. The rise was first significant at 300 minutes $(p<0 \cdot 05)$.

\section{POTASSIUM}

The mean plasma potassium concentration (table) did not change significantly during the equilibration period, the immediate preinfusion value being $3.87 \pm 0.04 \mathrm{mmol}(\mathrm{mEq}) / 1$. Ethanol infusion was accompanied by a fall to $3.38+0.04 \mathrm{mmol} / 1220$ minutes after the start of the infusion $(\mathrm{p}<0.05)$.

Glucagon had no significant effect on lactate, pyruvate, 3-hydroxybutyrate, acetoacetate, free fatty acids, cortisol, or potassium.

\section{Discussion}

\section{BLOOD ETHANOL}

All six subjects felt deeply intoxicated by the end of the experiment, and in view of the relatively low blood ethanol concentrations the hypoglycaemia probably partly accounted for this. At no time did blood ethanol concentrations exceed the legal limit for driving ( $370 \mathrm{mmol} / \mathrm{l} ; 80 \mathrm{mg} / 100 \mathrm{ml})$. 
PLASMA GLUCOSE, GLUCOSE TURNOVER, AND INSULIN

Our results show that ethanol induces hypoglycaemia in fasted subjects by inhibiting hepatic glucose production ( $\mathrm{Ra})$. The lack of response of plasma glucose to glucagon administration indicates that the 36-hour fast had depleted hepatic glycogen. $\mathrm{Ra}$ therefore represents entirely gluconeogenesis. Ethanol thus caused hypoglycaemia by inhibiting gluconeogenesis. This concurs with the observation of Freinkel et al that the rate of ${ }^{14} \mathrm{C}$-alanine cycling to glucose is decreased in liver slices from alcohol-fed rats compared with controls. ${ }^{3}$ Glucose utilisation (Rd) fell during ethanol administration, probably due to declining substrate availability. This contrasts with the findings of Searle et $a l,{ }^{4}$ who used a single bolus injection of ${ }^{14} \mathrm{C}-6$ glucose to measure glucose turnover during ethanol infusion in fasted subjects. In that study glucose turnover was calculated from small changes in the ${ }^{14} \mathrm{C}$-6-glucose specific activity decay curve. We have strong reservations about the accuracy of that method. Ethanol reportedly also inhibits gluconeogenesis in non-fasted subjects, ${ }^{10}$ but hypoglycaemia does not occur owing to accompanying glycogenolysis. ${ }^{11}$

The continuously low insulin concentrations, which were to be expected after a 36-hour fast, were lower than those found under similar circumstances by Joffe et al.12 Plasma insulin concentrations appeared to remain steady in our subjects. These were, however, below the lower limit of the assay for much of the experiment, and small variations may have gone undetected. Glucagon stimulates insulin release; nevertheless, the plasma insulin concentration failed to rise after glucagon administration, possibly because of the concomitant hypoglycaemia.

The increase in cytosolic and mitochondrial reduced nicotinamide-adenine-dinucleotide to oxidised nicotinamide-adeninedinucleotide (NADH:NAD ${ }^{+}$) ratios resulting from ethanol oxidation $^{5}$ may be the cause of gluconeogenesis inhibition.

Ethanol is oxidised principally in the liver by three separate mechanisms: (1) in the cytosol-the alcohol dehydrogenase reaction; (2) in the endoplasmic reticulum-the microsomal ethanol-oxidising system; (3) in the endoplasmic reticulumthe NADH oxidase/catalase system. The cytosolic alcohol dehydrogenase reaction (fig 4) is the major ethanol-oxidising mechanism. Both this and the endoplasmic reticulum reactions result in acetaldehyde production. The acetaldehyde is further oxidised to acetate. These two reactions produce $2 \mathrm{~mol} \mathrm{NADH}$ per mol of ethanol oxidised. During ethanol metabolism the rate of $\mathrm{NAD}^{+}$reduction exceeds mitochondrial $\mathrm{NADH}$ oxidation, thus increasing the cytosolic NADH:NAD ${ }^{+}$ratio. The shift in redox potential would be expected to decrease substrate (pyruvate, glycerol, alanine) availability for gluconeogenesis. ${ }^{3}$ Ylikahri, ${ }^{13}$ however, showed that ethanol may directly inhibit the first stage of gluconeogenesis, the carboxylation of pyruvate to oxaloacetate.

\begin{tabular}{|c|c|c|}
\hline ETHANOL + NAD $^{+}$ & 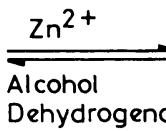 & $\begin{array}{l}=\text { ACETALDEHYDE }+\mathrm{NADH}+\mathrm{H}^{+} \\
\text {ase }\end{array}$ \\
\hline ACETALDEHYDE + & $\mathrm{H}_{2} \mathrm{O}+\mathrm{NAD}+$ & $\begin{array}{l}\rightleftharpoons \text { Acetaldehyde } \\
\text { Dehydrogenase }\end{array}$ \\
\hline
\end{tabular}

\section{METABOLITES}

The rise in blood lactate concentration was predicted from an increase in the rate of pyruvate reduction to lactate and a decrease in the rate of the reverse reaction, secondary to the redox changes. Though lactate concentration did not reach the values seen in diabetic lactic acidosis, the rate of rise was spectacular and showed no signs of decreasing at the end of the experiment. The use of ethanol in parenteral nutrition regimens, particularly in patients with impaired hepatic function, may predispose to significant lactic acidosis. In view of the high rate of lactate production, the low blood pyruvate concentrations were also expected. The small rise towards the end of the experiment may be explained by assuming a maximal rate of pyruvate reduction to lactate together with inhibition of oxidative phosphorylation and gluconeogenesis after the stage catalysed by lactate dehydrogenase, as suggested by Ylikahri. ${ }^{3}$ The striking increase in the lactate to pyruvate ratio reflects the accumulation of lactate. The lactate to pyruvate ratio gives an indication of the peripheral extramitochondrial NADH:NAD + ratio. These results therefore illustrate the profound reduction of redox state that accompanies ethanol oxidation. The change of redox potential is also responsible for the increase of 3-hydroxybutyrate, the decrease of acetoacetate, and the resulting rise of the 3-hydroxybutyrate to acetoacetate ratio.

The rises in blood glycerol and free fatty acid concentrations suggest an increase in the rate of lipolysis. This may be caused by either (a) stimulation of catecholamine release from the adrenal medulla by ethanol (increasing tissue lipase activity) or (b) low plasma insulin concentration, or both. The overall rise and initial fall in blood free fatty acid concentration during ethanol infusion has also been observed by others. ${ }^{2} 14$ These results differ from those of Abramson and Arky, ${ }^{6}$ who noted a decline in free fatty acid during ethanol infusion. This was due to a shorter (30-minute) infusion of ethanol. The rising free fatty acid and glycerol concentrations might also be accounted for by decreased utilisation. Lundquist $e t$ a ${ }^{15}$ showed a decline in glycerol uptake in the splanchnic bed of man during ethanol administration, and a decrease in oxidation of free fatty acids could be secondary to the redox shift.

The observed fall in plasma growth hormone concentrations contrasted with the increase in response to fasting or insulininduced hypoglycaemia. Arky and Freinkel ${ }^{7}$ and Priem et al ${ }^{16}$ published similar results. Evidence from Blackard et $a l^{1}$ ? shows that free fatty acids inhibit the release of growth hormone. The temporal correlation of a rise in free fatty acids and a fall in growth hormone in the present study supports this.

The overall response of cortisol was predictable, rising values being expected in response to progressive hypoglycaemia Nevertheless, the plasma cortisol concentration rose significantly before an appreciable degree of hypoglycaemia had occurred. Other studies suggest that ethanol has a direct effect on the hypothalamus-pituitary-adrenal axis and that stimulation of adrenocorticotrophic hormone may be its basis. This may partly explain the pseudo-Cushing syndrome which occurs in chronic alcoholism. ${ }^{18}$

There is widespread belief that potassium and glucose uptake by the tissues is linked. This hypothesis is inconsistent with the concomitant fall in plasma potassium concentration and $\mathrm{Rd}$ In view of the decline in $\mathrm{Ra}$, we suggest that hepatic potassium and glucose release is linked, as hypothesised by Zierler and Rabinowit $\mathrm{Z}^{19}$ and by Brown et al. ${ }^{20}$ Inhibition of gluconeogenesis in the fasted state may therefore cause hypokalaemia.

We conclude that ethanol induces hypoglycaemia in the fasted state by inhibiting gluconeogenesis. Accompanying this are widespread changes in intermediary carbohydrate and fat metabolism. These include raised lactate, 3-hydroxybutyrate, and free fatty acid concentrations. The observed reduction of redox state induced by ethanol oxidation probably explains these findings.

Ethanol-induced hypoglycaemia is accompanied by a reduction in growth hormone concentration, due possibly to inhibition of growth hormone release by free fatty acids. Plasma cortisol concentrations are raised during ethanol-induced hypoglycaemia, hypoglycaemia alone being an insufficient cause. A link between hepatic potassium and glucose release rather than peripheral potassium and glucose uptake is suggested.

Using ethanol as a source of energy in patients requiring parenteral nutrition may have serious consequences in hypoglycaemia, lactic acidosis, and hypokalaemia. 
We thank Sister $S$ Mee for help in performing these studies, Professor $\mathbf{R}$ Brooks for supervising the cortisol assays, and the Research Endowments Committee of St Thomas's Hospital and the British Diabetic Association for financial help.

Requests for reprints should be addressed to $\mathrm{N} M$ Wilson.

\section{References}

1 Brown TM, Harvey AM. Spontaneous hypoglycemia in "smoke" drinkers. ҰAMA 1941;117:12-5.

${ }^{2}$ Freinkel N, Singer DA, Arky RA, Bleicher SJ, Anderson JB, Silbert CK. Alcohol hypoglycemia I. Carbohydrate metabolism of patients with clinical alcohol hypoglycemia and the experimental reproduction of the syndrome with pure ethanol. 7 Clin Invest 1963;42:1112-33.

${ }^{3}$ Freinkel N, Cohen AK, Arky RA, Foster AE. Alcohol hypoglycemia II. A postulated mechanism of action based on experiments with rat liver slices. F Clin Endocrinol Metab 1965 ;25:76-94.

${ }^{4}$ Searle GL, Shames D, Cavalieri PR, Bagdade JD, Porte DJ. Evaluation of ethanol hypoglycemia in man. Turnover studies with ${ }^{14} \mathrm{C}-6$-glucose. Metabolism $1974 ; 23: 1023-35$

${ }^{5}$ Leiber CS. Metabolism and metabolic actions of ethanol. In: Freinkel N, ed. The year in metabolism 1975-6. New York: Plenum Medical, 1977 317-42.

6 Abramson EA, Arky RA. Acute antilipolytic effects of ethyl alcohol and acetate in man. $\mathcal{F}$ Lab Clin Med 1968;72:105-17.

7 Arky RA, Freinkel N. Alcohol hypoglycemia III. Effects of ethanol on plasma, glucose, ketone and free fatty acids in "juvenile" diabetics: a model for "nonketotic diabetic acidosis ?" Arch Intern Med 1964; 114:501-7.

${ }^{8}$ Bagdade JD, Gale CC, Porte D Jr. Hormone fuel interrelationships during alcohol hypoglycemia in man. Proc Soc Exp Biol Med 1972;141:540-2.
9 Steele R, Wall JS, De Bodo RC, Altszuler N. Measurement of size and turnover rate of body glucose pool by the isotope dilution method. Am f Physiol 1956;187:15-24.

${ }^{10}$ Kreisberg RA, Crawford Owen W, Siegel AM. Ethanol-induced hyperlacticacidemia: inhibition of lactate utilization. F Clin Invest 1971;50: 166-74.

11 Lochner A, Wulff J, Madison LL. Ethanol-induced hypoglycemia I. The acute effects of glucose output and peripheral glucose utilization in fasted dogs. Metabolism 1967;16:1-18.

12 Joffe BI, Shires R, Seftel HL, Heding LG. Plasma insulin, C-peptide, and glucagon levels in acute-phase ethanol-induced hypoglycaemia. $\mathrm{Br} \mathrm{Med}$ f 1977 ;ii :67-8.

13 Ylikahri RH. Ethanol-induced hypoglycemia in thyroxine-treated rats. Metabolism 1970;19:518-28.

14 Leiber CS, Leevy CM, Stein SW, et al. Effect of ethanol on plasma free fatty acids in man. $\mathcal{F} \mathrm{Lab}$ Clin Med 1962;59:826-32.

15 Lundquist F, Tygstrup N, Winkler KK, Jensen KB. Glycerol metabolism in the human liver: inhibition by ethanol. Science $1965 ; 150: 616-7$.

${ }^{16}$ Priem HA, Shanley BC, Malan C. Effect of alcohol administration on plasma growth hormone response to insulin-induced hypoglycaemia. Metabolism 1976;25:379-403.

17 Blackard WG, Boylen CT, Hinson TC, Nelson NC. Effect of lipid and ketone infusions on insulin-induced growth hormone elevations in rhesus monkeys. Endocrinology $1969 ; 85: 1180-5$.

18 Rees LH, Besser GM, Jeffcoate WJ, Gouldie DJ, Marks V. Alcoholinduced pseudo-Cushing's syndrome. Lancet $1977 ; \mathrm{i}: 726-8$.

19 Zierler KL, Rabinowitz DJ. Effects of very small concentrations of insulin on forearm metabolism. Persistence of its action on potassium and free fatty acids without its effect on glucose. $\mathcal{F}$ Clin Invest $1964 ; 43: 950-62$.

${ }^{20}$ Brown PM, Tompkins CV, Juul SA, Sönksen PH. Mechanism of action of insulin in diabetic patients : a dose-related effect on glucose production and utilisation. $\mathrm{Br}$ Med $\mathcal{F} 1978 ; \mathrm{i}: 1239-42$.

(Accepted 6 January 1981)

\title{
Biochemical tests for diagnosis of phaeochromocytoma: urinary versus plasma determinations
}

\author{
P F PLOUIN, J M DUCLOS, J MENARD， E COMOY，C BOHUON，J M ALEXANDRE
}

\begin{abstract}
Fifteen patients with hypertension due to phaeochromocytoma and 35 controls with essential hypertension were studied to assess the diagnostic value of urinary and plasma biochemical determinations in phaeochromocytoma.

In every case of phaeochromocytoma the urinary concentration of vanillylmandelate, metanephrines, or adrenaline plus noradrenaline was diagnostic of the disease irrespective of whether the patient was normotensive or hypertensive at the time. Plasma determinations of adrenaline and noradrenaline, however, gave falsely negative results on three occasions.
\end{abstract}

These findings suggest that urinary biochemical deter-

\footnotetext{
Hypertension Clinic and Department of Urology, Hôpital SaintJoseph, 75674 Paris Cedex 14

P F PLOUIN, MD, assistant in medicine

J M DUCLOS, MD, assistant in urology

J MENARD, MD, associate professor

Department of Clinical Biochemistry, Institut Gustave Roussy, 94800 Villejuif

E COMOY, PHD, assistant

C BOHUON, PHD, associate professor

Department of Pharmacology, Hôpital Broussais, 75014 Paris J M ALEXANDRE, MD, associate professor
}

minations-particularly of metanephrines-are more reliable than plasma catecholamine measurements as a test for phaeochromocytoma. The test is particularly useful in patients with intermittent hypertension."

\section{Introduction}

Diagnosing phaeochromocytoma is easy in patients with sustained hypertension: measurement of 24-hour excretion of vanillylmandelate, metanephrines, and catecholamines suffices to confirm or exclude the presence of the tumour. ${ }^{1}$ Diagnosis is harder to establish when hypertension is intermittent, however, since tumoral secretion of catecholamines may be absent during normotensive periods. To assess the diagnostic value of urinary and plasma determinations in phaeochromocytoma, we measured urinary concentrations of catecholamine metabolites and resting plasma concentrations of catecholamines in 15 patients with phaeochromocytoma, four of whom had intermittent hypertension.

\section{Methods}

In 15 hypertensive patients the diagnosis of phaeochromocytoma was based on biochemical tests and confirmed at operation. Thirtyfive other patients diagnosed by conventional methods as having essential hypertension were used as controls. No patient received any treatment for 15 days before testing. A 24-hour urine collection was assayed for vanillylmandelate, metanephrine, and adrenaline 